\title{
PEMBINAAN KEAGAMAAN PADA NARAPIDANA ANAK (STUDI DESKRIPTIF PADA LEMBAGA PEMASYARAKATAN ANAK KELAS III BANDUNG)
}

\author{
Widya Haryanti, ${ }^{*}$ \\ Toto Suryana, Endis Firdaus, \\ Program Studi Ilmu Pendidikan Agama Islam, \\ Fakultas Ilmu Pengetahuan Sosial, Universitas Pendidikan Indonesia \\ *Email :widya_haryanti@gmail.com
}

\begin{abstract}
ABSTRAK
Artikel ini dilatar belakangi oleh perma-salahan yang terjadi dikalangan anak dan remaja atau yang dikenal dengan juvenile deliquency. Hal tersebut disebabkan oleh pergaulan yang tidak baik, pendidikan yang kurang, pengawasan orang tua yang lemah sehingga anak merasa dirinya tidak diperhatikan dan melakukan tindakan yang melanggar hukum. Anak yang melakukan tindakan pidana atau melanggar hukum mereka perlu mendapat perhatian dan pembinaan yang khusus agar mereka tidak mengulangi kesalahan yang pernah dilakukan. Tujuan diadakan pembinaan keagamaan terhadap anak yang melanggar hukum adalah anak menyadari kesalahannya dan tidak mengulanginya kembali serta memperbaiki diri agar menjadi manusia yang lebih baik. Anak tersebut diserahkan dan dibina di Lembaga Pemasyarakatan, salah satunya lembaga Pemasyarakatan Anak Kelas III Bandung.

Penelitian ini bertujuan untuk mengetahui bagaimana perencanaan, pelaksanaan dan hasil program pembinaan keagamaan di lapas anak Bandung. Penelitian ini menggunakan metode dekriptif dengan pendekatan kualitatif. Pengumpulan data melalui wawancara, observasi dan studi dokumentasi. Adapun untuk perencanaan petugas dengan ustaż yang mengajar melakukan rapat untuk menyusun program tersebut sesuai dengann kebutuhan anak yang ada di lapas tersebut. Dalam kegiatan pelaksanaan program sudah berjalan sesuai dengan jadwal yang direncanakan. Metode yang digunakan disesuaikan dengan materi yang akan disampaikan seperti metode ceramah dan tanya jawab, metode bercerita dan metode menghafal. Penilaian yang dilakukan adalah penilaian sikap berupa penilaian lisan bukan dalam bentuk angka. Hal yang terpenting dari program pem-binaan keagamaan yang ada di lapas adalah anak tidak mengulangi kesalahannya dan tidak kembali lagi ke lapas serta diterima dengan baik oleh masyarakat.
\end{abstract}

Kata Kunci: Juvenile Deliquency, Pembinaan Keagamaan, Lembaga Pemasyarakatan Anak. 


\section{PENDAHULUAN}

Manusia sebagai fitrahnya tidak bisa hidup sendiri, mereka membutuhkan orang lain untuk berinteraksi demi kelangsungan hidupnya. Interaksi dan perkembangan sosial anak telah dimulai sejak masa bayi, kemudian pada masa kanak-kanak dan selanjutnya pada masa remaja. Interaksi sosial anak dimulai dari lingkungan terkecil yaitu lingkungan keluarga khususnya ibu dan ayahnya. Kemudian berkembang keanggota keluarga lainnya, teman bermain dan lingkungan sekitar. Pada masa anak usia sekolah, maka terjadilah perubahan hubungan anak dan orang tuanya. Hal ini disebabkan karena adannya peningkatan penggunaan waktu yang dilewati anak- anak bersama teman sebayanya (Desmita, 2011, hal. 220).

hadis di atas setiap anak yang dilahirkan secara fitrah, fitrah yang dimaksud adalah Islam. Fitrah Islam adalah potensi Allah kepada anak yang dilahirkan, hingga tatkala dewasa ia bisa melaksanakan syari'ah secara sempurna. Namun meskipun anak itu sudah dibekali fitrah tetapi tetap mendapatkan godaan setan dan godaan dari lingkungannnya. Oleh karena itu, orang tua, pendidik dan masyarakat bertanggung jawab atas anak agar tidak menyimpang dari fitrah Islamnya. Apakah anak tetap dalam fitrah islam, ataukah Yahudi, Nasrani dan Majusi. Oleh karena itu, orang dewasa bertanggung jawab mendidik anak menjadi muslim yang paripurna (Arifin, 1982, hal. 29).

Sedangkan menurut Piaget (dalam Hurlock, 1980, hal. 206), secara psikologis masa remaja adalah usia dimana individu berintergrasi dengan masyarakat dewasa, usia dimana anak tidak lagi berada dibawah tingkat orang yang lebih tua melainkan dengan tingkat yang sama, sekurang-kurangnya dalam masalah hak.

Pada masa remaja, perkembangan tersulit yang dialami adalah penyesuaian diri dengan lingkungan sekitar atau yang lebih dikenal dengan penyesuaian sosial. Untuk mencapai pola sosialisasi dewasa,
Dalam Arifin, (1982, hal. 28) hadis Bukhārī menjelaskan bahwa setiap anak dilahirkan dalam keadaan fitrah dan pengaruh pendidikan orang tua terhadap anak.

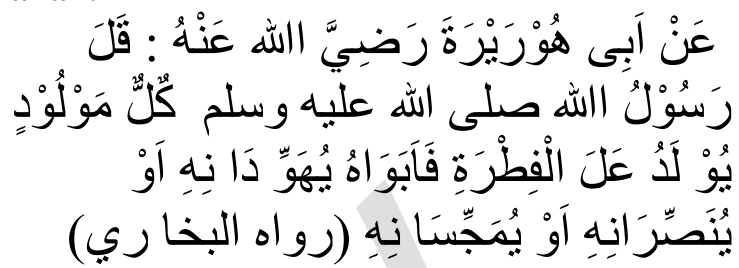

Artinya: Dari Abu Hurairah ra, Rasulullah

Saw berkata: Setiap anak itu dilahirkan dalam keadaan fitrah. Kedua orang tuanyalah yang membuatnya menjadi Yahudi, seorang Nasrani maupun Majusi (HR. Bukhārī).

Penjelasan

remaja harus membuat penyesuaian baru. Dalam penyesuaiannya yang terpenting dan tersulit adalah penyesuaian diri dengan meningkatkan pengaruh kolompok sebaya, perubahan dalam perilaku sosial, pengelompokan sosial yang baru, nilainilai baru dalam seleksi persahabatan, nilai-nilai baru dalam dukungan dan penolakan sosial, dan nilai-nilai baru dalam seleksi pemimpin (Nursihan \& Agustin, 2011, hal. 67).

Pada masa remaja konflik antara orang tua dan anaknya cenderung meningkat. Masa remaja awal adalah suatu periode ketika konflik dengan orang tua meningkat melampaui tingkat masa anakanak. Peningkatan ini dapat disebabkan oleh beberapa faktor yaitu perubahan biologis pubertas, perubahan kognitif yang meliputi peningkatan idealisme dan penalaran logis, perubahan sosial yang berfokus pada kemandirian dan identitas perubahan kebijaksanaan pada orang tua, dan harapan-harapan yang dilanggar oleh pihak orang tua dan remaja (Hurlock, 1980, hal. 232).

Dari penjelasan di atas, penulis berpendapat bahwa orang tua yang melihat anaknya yang tidak mau lagi mendengarkan nasehat-nasehat yang 
mereka katakan, sehingga orang tua menetapkan standar-standar yang harus dituruti oleh seorang anak, agar anak mereka tidak melakukan penyimpanganpenyimpangan dan dapat mempertanggung jawabkan apa yang mereka lakukan. Sementara anak berpandangan bahwa standar-standar yang ditetapkan oleh orang tua merupakan pengekangan hak mereka yang menjadikan mereka tidak bebas melakukan apa yang mereka inginkan.

Dalam upaya pelaksanaan pembinaan atau bimbingan pada anak, sering di jumpai permasalahan dan tantangan dimana anak sering melakukan prilaku menyimpang bahkan cenderung melakukan pelanggaran yang melanggar hukum. Perbuatan menyimpang pada remaja dikenal dengan istilah Juvenile Deliquency. Juvenile Deliquency berasal dari bahasa Latin yaitu juvenilis artinya anak-anak, anak muda, ciri karakteristik pada masa muda, sifat-sifat khas pada periode remaja. Sedangkan Delinquent berasal dari kata Latin, Delinquere berarti terabaikan, menagabaikan, yang kemudian diperluas artinya menjadi jahat, a-sosial, kriminal, pelanggaran aturan, pembuat ribut, pengacau, penteror, dursila, dan lainlain (Kartono, 2014, hal. 6).

Sedangkan menurut Romli Atmasasmita(dalam Soetodjo, 2010, hal. 11)Juvenile Delinquency adalah setiap perbuatan atau tingkah laku seseorang anak dibawah umur 18 tahun dan belum kawin yang merupakan pelanggaran terhadap norma-norma hukum yang berlaku serta dapat membahayakan perkembangan pribadi sianak yang bersangkutan.

Maka untuk mencegah terjadinya kenakalan remaja, maka orang tua, lingkungan dan masyarakat sama-sama membantu remaja agar tidak melakukan prilaku menyimpang.

Dalam QS. Al-Tahrīm [66] : 6 menjelaskan tentang keluarga adalah sebagai berikut:
Artinya: Hai orang-orang yang beriman, peliharalah dirimu dan keluargamu dari api neraka yang bahan bakarnya adalah manusia dan batu; penjaganya malaikatmalaikat yang kasar, keras, dan tidak mendurhakai Allah terhadap apa yang diperintahkan-Nya kepada mereka dan melakukan selalu mengerjakan apa yang diperintahkan (QS. Al-Taḥī̄m [66] : 6).

Ayat di atas menjelaskan bahwa wajib bagi orang tua untuk mendorong kelurganya (anak-anaknya) untuk perbuatan yang ma'ruf dan mencegah mereka untuk melakukan hal yang mungkar. Orang tua harus memerintahkan anaknya untuk mengerjakan shalat, menunaikan zakat, menjalankan puasa dan semua kewajiban Islam dan memerintahkan anak-anak mereka untuk berakhlak yang baik dan adab yang bagus.

Berdasarkan Wawancara yang dilakukan oleh peneliti dengan petugas Lembaga pemasyarakatan (Lapas) anak kelas III Bandung, peneliti memperoleh data terdapat \pm 57 anak yang melakukan tindak pidana.

Adanya pelaksanaan pembinaan di lapas bertujuan untuk mereka yang melakukan tindak pidana tersebut bertanggung jawab terhadap dirinya dan masyarakat, sehingga mereka berhenti dari prilaku kejahatan seperti yang pernah dilakukan sebelumnya. Namun kenyataan di lapangan masih banyak masalah yang terjadi di lapas seperti adanya "Residivis", melarikan diri dari penjara, mengendalikan kejahatan dari dalam penjara dan lain sebagainya(Nurlaen, 2012, hal. 19). Berdasarkan hasil wawancara penelit di Lembaga Pemasyarakatan anak di Bandung terdapat 1 orang anak dalam kasus residivis.

Oleh karena itu, peneliti merasa tertarik untuk meneliti masalah tentang "Pembinaan Keagamaan Pada Narapidana Anak (Studi Deskriptif 
Pada Lembaga Pemasyarakatan Anak Kelas III Bandung). Karena, masalah ini perlu perhatian lebih dalam oleh pemerintah, lembaga pemerhati anak, kaum akademisi dan masyarakat umum.

\section{METODE}

Dalam penelitian ini, $\begin{array}{r}\text { peneliti } \\ \text { kualitatif }\end{array}$
menggunakan pendekatan
dengan metode deskriptif. Penelitian
deksripsi adalah akumulasi data dasar
dalam cara deskriptif semata-mata tidak
perlu mencari atau menerangkan saling
hubungan, mentest hipotesis, membuat
ramalan atau mendapatkan makna dan
implikasi, walaupun penelitan bertujuan
menemukan hal-hal tersebut dapat
mencakup juga metode-metode
deksriptif(Suryabarata, 2012, hal. 76).

Dalam penelitan ini, peneliti melakukan penelitian dengan menggambarkan secara rinci dan mendalam tentang segala sesuatu yang ada dan terjadi terkait dengan perencanaan, pelaksanaan dan hasil dari kegiatan pembinaan keagmaan di lapas anak Bandung. Sebelum terjun ke lapangan, peneliti harus mempersiapkan terlebih dahulu apa saja yang akan dipersiapkan dan dibutuhkan selama penelitian Adapun subjek dalam penelitian ini adalah Kepala seksi bidang pembinaan, staf seksi bidang pembinaan, ustaż yang mengajar di lapas dan 5 orang anak didik pemasyarakatan yang berumur 13- 18 tahun.

Penelitian yang peneliti lakukan bertempat di Lembaga Pemasyarakatan Anak Kelas III Bandung yang beralamat di Jalan Pacuan Kuda no 3A Arcamanik Bandung. Adapun alasan peneliti mengambil tempat penelitian ini adalah karena Lembaga Pemasyarakatan anak sudah terpisah dari orang dewasa dan satusatunya lembaga pemasyarakatan anak di Bandung. Selain itu, melihat kebutuhan data peneliti yang dilihat dari, jumlah anak, sumber daya manusia yang memadai dan program kegiatan pembinaan keagamaan yang ada di lapas anak tersebut, membuat peneliti tertarik melakukan penelitian di Lembaga Pemasyarakatan Anak Kelas III Bandung.

Teknik pengumpulan data merupakan langkah yang paling utama dalam penelitian, karena tujuan utama dari penelitian adalah mendapatkan data. Oleh karena itu, dalam data penelitian kualitatif diperoleh dari sumber data dengan menggunakan teknik pengumpulan data yang dapat dikelompokkan menjadi empat macam, diantaranya adalah wawancara, observasi, dokumentasi dan triangulasi.

Uji validitas dalam penelitian ini di lakukan beberapa hal, yaitu:

Triangulasi dapat diartikan sebagai teknik pengumpulan data yang bersifat menggabungkan dari beberapa teknik pengumpulan data dan sumber data yang telah ada. Ketika peneliti mengumpulkan data dengan triangulasi, maka peneliti mengumpulkan data sekaligus menguji kredibilitas/validitas data, yaitu kredibilitas dengan teknik pengumpuan data dan berbagai sumber data(Sugiyono, 2013, hal. 330).

Member check adalah proses pengecekan data yang diperoleh oleh peneliti kepada pemberi data. Adapun tujuan dari member check adalah untuk mengetahui seberapa jauh data yang diperoleh sesuai dengan data yang di berikan oleh pemberi data. Apabila data yang di temukan di sepakati oleh pemberi data berarti data tersebut valid, dan semakin kredibel/ dipercaya (Sugiyono, 2013, hal. 375).

Data yang sudah didapat melalui teknik pengumpulan tersebut, langkah selanjutnya adalah dengan menganalisis data. Dari data tersebut dianalisis dengan mereduksi data dengan cara memilih data yang dibutuhkan, setelah itu dikategorisasikan dengan menggunakan koding. Data yang sudah direduksi lalu disajikan dalam display data dengan uraian singkat secara deskriptif dan setelah semuanya selesai tahap selanjutnya adalah menyimpulkan (verification). 


\section{HASIL DAN PEMBAHASAN}

1. Profil Lembaga Pemasyarakatan Anak Kelas III Bandung

Lembaga Pemasyarakatan Anak Kelas III Bandung terletak di Lapas Sukamiskin dan Lapas Wanita yang beralamat di jl. Pacuan Kuda no. 3A, Arcamanik Bandung. Lapas Anak mulai beroperasi pada tanggal 8 April Tahun 2013 dengan Luas Tanah 18.200. Saat ini lapas anak dapat menampung 48 anak. Namun jika sudah rampung lapas anak diperkiraan dapat menampung sekitar 468 penghuni.

Visi dari lembaga pemasyarakatan anak Bandung adalah memulihkan kesatuan hubungan hidup, kehidupan dan penghidupan anak sebagai individu, anggota mayarakat dan makhluk Tuhan Yang Maha Esa dan menjadi istitusi yang dibanggakan dalam memberikan pembinaan yang beriman, berilmu dan bermanfaat kepada anak didik pemasyarakatan.

Adapun

Misi lembaga

pemasyarakatan anak Bandung adalah Membentuk anak didik pemasyarakatan menjadi manusia yang beriman, berilmu dan bertaqwa kepada Tuhan Yang Maha Esa, yang memiliki kecendrungan hidup. mewujudkan keseimbangan, kemajuan anak didik pemasyarakatan dari aspek kognitif, afektif dan psikomotor yang berperan sebagai individu, anggota keluarga, masyarakat dan makhluk Tuhan Yang Maha Esa, memulihkan kualitas hubungan anak dengan keluarga dan masyarakat melalui upaya reintegrasi sosial, mewujudkan kepentingan terbaik bagi anak, perlindungan, keadilan, non diskriminasi dan penghargaan terhadap pendapat anak, melaksanakan pelayanan, perawatan, pendidikan, pembinaan, pembimbingan dan pemdampingan tumbuh kembang anak, meningkatkan ketaqwaan, kecerdasan, kesantunan dan keceriaan anak agar dapat menjadi manusia mandiri dan bertanggung jawab, menjadkan lembaga yang layak dan ramah anak, serta mempersiapkarn anak didik pemasyarakatan agar mempunyai kemampuan untuk berperan aktif dalam pembangunan setelah kembali lagi ke masyarakat.

Sedangkan Tujuan dari lembaga pemasyarkatan anak bandung adalah melaksanakan pelayanan terhadap anak didik pemasyarakatan sesuai dengan ketentuan perundang-undangan.

2. Perencanaan pembinaan keagamaan Pada Narapidana Anak Kelas III Bandung.

Berdasarkan Hasil wawancara dengan Kepala Sub Seksi Pembinaan Lembaga Pemasyarakatan Anak Kelas III Bandung yakni Bapak Roni Nulyadi pada tanggal 30 April 2015, beliau menyatakan bahwa perencanaan program pembinaan keagamaan di lapas anak Bandung berdasarkan rapat yang dilakukan oleh kepala sub seksi pembinaan dan para ustaż yang mengajar di lapas anak tersebut. Dari rapat tersebut maka tersusunlah program pembinaan keagamaan. Yang menjadi pertimbangan dalam menyusun program tersebut adalah subjek pembinaan itu sendiri yakni anak yang berada di lapas disamping mempertimbangkan 3 hal lainnya yaitu sumber daya manusia, sarana dan prasarana yang menunjung dan keuangan yang memadai.

Senada dengan bapak Roni, ibu Gina selaku staf pembinaan keagamaan juga berpendapat bahwa perencanaan program pembinaan keagamaan dilakukan melalui rapat dengan mempertimbangkan anak yang berada di lapas tersebut. Akan tetapi, beliau menambahkan program pembinaan keagamaan tidak ada kurikulum tertulis.

Jadwal kegiatan andikpas hanya dijadwalkan di white board yang sewaktuwaktu bisa berubah. Untuk jadwal pesantren, pramuka dan senam pagi itu sudah di jadwalkan waktunya. Pesantren setiap hari selasa- sabtu pukul 08.3010.30. Pramuka pada hari senin pukul 10.00- 12.00 dan jadwal senam itu setiap jum'an pagi. 
Nama program pembinaan keagamaan secara khusus tidak ada, tapi program secara keseluruhan adalah pembinaan mental spiritual. Program pembinaan keagamaan yang ada di lapas sudah berbasis pesantren. Meskipun pesantrennya tidak bisa disamakan dengan pesantren pada umumnya.

Pesantren di lapas tidak bisa disamakan dengan pesantren pada umumnya karena di lapas anak bandung belum ada ustaż yang mengontrol kegiatan keagamaan anak selama 24 jam, biasanya ustaż bekerja sama dengan sipir yang ada dilapas anak bandung untuk melihat aktiftas anak selama di blok. Seperti șalat berjamaah.

Program pembinaan keagamaan yang berbasis pesantren, anak-anak dibagi menjadi tiga kelas ada kelas A, B dan C. Anak- anak yang masuk ke kelas A itu sudah bisa membaca al-qur'an dengan lancar dan tajwid dengan benar. Anakanak yang masuk ke kelas B, yaitu anak yang sudah bisa membaca Al-Qur'an namun masih banyak perbaikan dan kelompok $\mathrm{C}$, yaitu anak yang sama sekali belum bisa baca tulis Al-Quran jadi mereka belajar dengan menggunakan iqra'. Selain itu juga, ada kegiatan pesantren atau kegiatan ceramah yang lebih terarah kepada tadabur Al-Qur'an iqra'.Jumlah anak berdasarkan pembagian kelas A, B, dan C yakni, Kelas A sebanyak 28 orang, kelas B sebanyak 26 orang dan kelas C sebanyak 54 orang.

Tujuan dari program pembinaan keagamaan sendiri adalah secara umum meningkatkan kualitas ketaqwaan kepada Tuhan Yang Maha Esa. Secara Khusus pembinaan bertujuan untuk memberikan pemahaman dasar agama kepada andikpas agar menjadi lebih baik dan menjadikan andikpas dari yang tidak bisa membaca Al-Qur'an menjadi lancar membaca AlQur'annya. Selain itu menjadikan andikpas manusia yang bertanggung jawab.

Sedangkan target pencapaian program pembinaan keagamaan adalah menjadikan andikpas memiliki akhlak mulia, andikapas menjadi lebih baik lagi dan yang terpenting tidak mengulangi perbuatannya serta tidak kembali lagi ke lapas.

Untuk evaluasi program yang direncanakan adalah penilaian sikap dan pengamatan prilaku yang bersifat lisan. Pengamatan perilaku formatnya diatur di dalam buku pembinaan anak. Berbagai aspek dinilai dari mulai keadaan fisik, mental psikologis, sosial kemasyarakatan, kedisiplinan, dan profesionalisme pekerjaan.

3. Pelaksanaan pembinaan keagamaan pada narapidana anak kelas III Bandung

Pelaksanaan atau pergerakkan dalam manajemen adalah penempatan semua anggota atau kelompok agar bekerja secara sadar untuk mencapai tujuan yang telah ditetapkan sesuai dengan perencanaan yang telah disusun(Ramayulis, 2012, hal. 381).

Pembinaan keagamaan anak usia dini Langkah-langkah yang dilakukan dalam program pembinaan keagamaan adalah semua anak dibariskan di halaman mesjid atau di depan blok, disuruh berhitung, dan masuk ke dalam mesjid secara tertib. Setelah mereka masuk ke dalam masjid, mereka mengaji bersama dengan ustaż, setelah mengaji bersama maka semua peserta mendengarkan penjelasan dari ustaż sesuai tema, setelah pematerian selesai, anak-anak dibariskan kembali dan berhitung setelah berhitung mereka masuk ke dalam blok masing-masing.

Adapun kegiatan keagamaan yang dilaksanakan di Lapas Anak Bandung kegiatan pesantren. Kegiatan pesantren meliputi kegiatan pengajian dan pembinaan baca tulis Al-qur'an. Pembinaan keagamaan dilaksanakan setiap hari selasa sampai hari sabtu. Kegiatan pesantren dimulai pukul 08.30 sampai pukul 10.30. waktu yang sudah ditentukan itu dibagi kedalam dua sesi.

Metode yang paling sering digunakan dalam pembinaan keagamaan adalah metode ceramah dan tanya jawab. Selain 
itu metode yang digunakan adalah metode bercerita, metode menghafal dan metode yang berpusat pada client. Metode menghafal digunakan untuk menghafal Alqur'an atau tahfiz, metode client of centered adalah metode yang berpusat pada client kalau di lapasa yaitu andikpas itu sendiri. Biasanya materi yang menggunakan metode ini adalah tentang parenting, dan metode yang digunakan untuk menyampaikan sejarah nabi adalah metode bercerita.

Adapun menurut Arifin, (2007, hal. 55-59) mengemukakan beberapa metode pendidikan untuk meningkatkan kesadaran hukum anak didik lapas, adalah sebagai berikut: metode peringatan dan pemberian motivasi, dengan memberikan peringatan dan motivasi diharapakan mereka meninggalkan perbuatan yang dilarang agama dan melakukan apa yang dianjurkan oleh agama. Metode hukuman, metode ini merupakan metode edukatif dengan maksud bahwa semua perbuatan yang dilakukan harus ada konsekuensinya. Jika perbuatan itu baik maka akan mendapatkan ganjaran yang sama dan jika perbuatan itu melanggar aturan maka seseorang tersebut akan mendapatkan ganjaran atau hukuman dengan tujuan adanya efek jera terhadap pelaku yaitu tidak mengulang perbuatannya lagi.

4. Hasil pembinaan keagamaan pada narapidana anak kelas III Bandung Penilaian atau evaluasi yang dilakukan dilapas anak Bandung adalah evaluasi bentuk lisan disampaikan oleh petugas pembinaan kepada Kepala Seksi Bagian Pembinaan ataupun kepada wali. Sedangkan untuk evaluasi bentuk perilaku sudah ada formatnya tersendiri dan wali hanya tinggal mengisi atau melengkapi nya saja. Pedoman penilaian dari pembinaan yaitu sudah terjadinya perubahan perilaku dari pertama masuk sampai saat ini, seperti mengetahui kesalahannya, bersikap baik, sopan, santun, mengikuti seluruh tahapan pembinaan.
Kriteria ketercapaian atau keberhasilan dari pembinaan ini yakni anak tidak kembali lagi ke lapas. Dalam artian anak tidak mengulangi tindak pidana yang dapat menyebabkan dia kembali menjadi narapidana. Namun, selalu saja ada masalah yang menyebabkan anak tersebut kembali melakukan tindak pidana, salah satu diantaranya penerimaan dari lingkungan masyarakat itu sendiri. Masyarakat masih belum mampu menerima mantan narapidana karena stigma masyarakat bahwa mantan narapidana bukan lagi orang yang baik dan santun, yang sewaktu-waktu dapat mengulangi tindakan pidana.

Masih ada anak yang terkena kasus residivis yaitu, anak telah melakukan tindakan hukum yang telah dihukum di lapas setelah bebas masa tahanan mereka kembali lagi mengulangi kesalahan dan mereka kembali lagi ke lapas. Dalam hal pembinaan keagamaan mereka disamakan dengan anak yang dilapas, akan tetapi dibedakan dalam bidang pengawasan.

Hambatan yang ditemukan oleh petugas dan pengajar dalam pelaksanaan pembinaan keagamaan adalah yakni sumber daya manusia, keuangan, dan sarana prasarana. Upaya yang dilakukan untuk mengatasi hambatan itu yaitu melakukan koordinasi dan komunikasi bahwa anak ini merupakan tanggung jawab bersama, bukan hanya instansi Kementrian Hukum dan HAM dan Lembaga Pemasyarakatan. Melalui kerjasama dengan Kementrian Agama, Lembaga Swadaya Masyarakat.

Hambatan yang dialami andikpas itu berupa materi yang membosankan, sarana dan prasarana dan keuangan. Upaya yang dilakukan petugas yag memberikan materi pembinaan harus melakukan inovasi agar dapat menghilangkan kejenuhan, bukan hanya satu arah tatapi melibatkan anak agar lebih interaktif. Kalau untuk sarana prasarana dan keuangan hanya memanfaatkan yang ada. 
Manfaat Pembinaan keagamaan yang dirasakan oleh andikpas adalah dapat menambah wawasan tentang keagamaaan, mereka bisa belajar membaca Al-qur'an, mereka lebih hati-hati dalam bersikap. Perubahan prilaku yang dialami andikpas adalah ibadah kepada Allah meningkat, seperti tidak meninggalkan șalat lima waktu, sering melakukan șalat-șalat sunnah dan melakukan puasa sunnah.

\section{KESIMPULAN}

Dapat disimpulkan perencanaan pembinaan keagamaan pada narapidana anak memiliki tujuan secara umum meningkatkan kualitas ketaqwaan kepada Tuhan Yang Maha Esa. Secara Khusus pembinaan bertujuan untuk memberikan pemahaman dasar agama kepada andikpas agar menjadi lebih baik dan menjadikan andikpas dari yang tidak bisa membaca Al-Qur'an menjadi lancar membaca AlQur'annya. Selain itu menjadikan andikpas manusia yang bertanggung jawab.

Penilaian program pembinaan keagamaan hanya menilai aspek afektif saja dengan hasil berupa lisan dan penilaian prilaku melalui pengamatan yang dilakukan anak lapas oleh petugas, sedangkan untuk penilaian aspek kognitif dengan ujian dalam bentuk angka itu tidak ada. Penilaian tersebut telah sesuai dengan tujuan program itu sendiri, karena penilaian sikap dan prilaku seseorang tidak dapat diukur dengan angka akan tetapi dilihat dari prilakunya dalam keseharian selama berada di lapas.

Manfaat yang dirasakan oleh andikpas selama mengikuti program pembinaan keagamaan adalah dapat menambah wawasan tentang keagamaaan, mereka bisa belajar membaca Al-qur'an, mereka lebih hati-hati dalam bersikap. Perubahan prilaku yang dialami andikpas adalah ibadah kepada Allah meningkat, seperti tidak meninggalkan shalat lima waktu, sering melakukan shalat-shalat sunnah dan melakukan puasa sunnah.

\section{REFERENSI}

(2002). Al-Qurān dan Terjemahannya, Penerjemah Tim Depag RI. Jakarta: CV Darus Sunnah

Arifin. (2007). Pendidikan Anak Berkonflik Hukum. Bnadung : Alfabeta.

Arifin, M. (1982). Pedoman Pelaksanaan Bimbingan dan Penyuluhan Agama. Jakarta: Golden Terayon.

Basrowi, \& Suwandi. (2008). Memahami Penelitian Kualitatif Jakarta: Rineka Cipta .

Hurlock, E. B. (1980). Psikologi Perkembangan. (R. M. Sijabat, Penyunt., Istiwidayanti, \& Soedjarwo, Penerj.) Jakarta: PT. Gelora Aksara Pratama.

Kartono, K. (2014). Patologi Sosial 2 Kenakalan Remaja. Jakarta: PT. Rajagrafindo Persada.

Nurihsan, A. J., \& Agustin, M. (2011). Dinamika Perkembangan Anak dan Remaja. Bandung: Refika Aditama.

Nurlaen, Y. (2012). Lembaga Pemasyarakatan Masalah \& Solusi. Bandung: Marja.

Priyatno, D. (2013). Sistem Pelaksanaan Pidana Penjara Di Indonesia. Bandung: PT. Refika Aditama.

Ramayulis. (2012). Ilmu Pendidikan Islam. Jakarta: Kalam Mulia.

Satori, D., \& Komariah, A. (2013). Metodelogi Penelitian Kualitatif. Bandung: Alfabeta. 
Soetodjo, W. (2010). Hukum Pidana Anak. Bandung: PT. Refika Aditama.

Sudjana. (1992). Pengantar Manajemen Pendidkan Luas Sekolah. Bandung: Nusantara Press.

Sugiyono. (2015). Metode Penelitian Pendidikan Pendekatan Kuantitatif, Kualitatif, dan $R \& D$. Bandung: Alfabeta.

Suryabrata, S. (2012). Metodologi Penelitian. Jakarta : Rajagrafindo Persada.

Ulwan, A. N. (2012). Pendidikan Anak dalam Islam. (A. Ahmad Ma'ruf Asrori, Penyunt., \& J. Miri, Penerj.) Jakarta: Pustaka Amani. 